удк 517.977.54:519.876.5

DOI: https://doi.org/10.32851/2708-0366/2021.10.20

Ларченко О.В.

кандидат сільськогосподарських наук, доцент, Херсонський державний аграрно-економічний університет ORCID: https://orcid.org/0000-0001-7857-0802

Larchenko Oksana

Kherson State Agrarian and Economic University

\title{
ВИКОРИСТАННЯ ІМІТАЦІЙНОГО МОДЕЛЮВАННЯ ПІД ЧАС РОЗВ'ЯЗАННЯ ЗАДАЧ ЕКОНОМІЧНОЇ ОПТИМІЗАЦІЇ
}

\author{
THE USE OF SIMULATION MODEL IN GINSOLVING \\ THE PROBLEMS OF ECONOMIC OPTIMIZATION
}

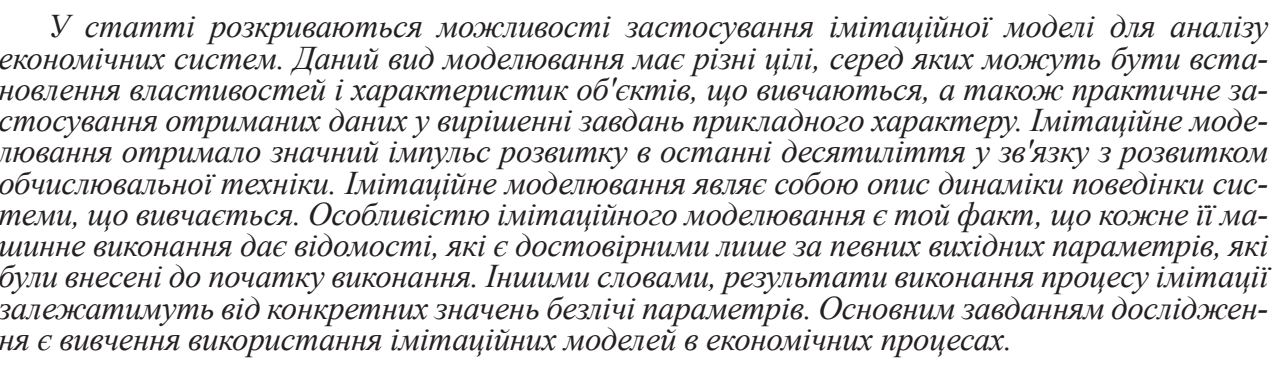

Ключові слова: імітаціийне моделювання, коваріація, кореляція, верифікація моделі, валідація, визначення рівня адекватності.

В статье раскрываются возможности применения имитационной модели для анализа экономических систем. Данный вид моделирования имеет различные иели, среди которых могут быть установление свойств и характеристик изучаемых объектов, а также практическое применение полученных данных в решении задач прикладного характера. Имитационное моделирование представляет собой описание ди ᄀнамики поведения изучаемой системьл. Особенностью имитациионного моделирования является тот факт, что каждое ее машинное выполнение дает сведения, которые являются достоверными только при определенных исходных параметрах, которые были в нее внесены до начала выполнения. Другими словами, результаты выполнения процесса имитации будут зависеть от конкретньх значений множества параметров. Основной задачей, которая стояла в данном исследовании, являлось изучение использования имитационных моделей в экономических процессах.

Ключевые слова: имитацчионное моделирование, ковариацчия, корреляция, верификация модели, валидация, определение степени адекватности.

The present article reveals the possibilities of applying simulation modeling in the economic systems analysis. This type of modelling aims at establishing the features and characteristics of different objects, as well as the practical use of the findings obtained in solving applied tasks. The simulation modeling received an important impetus to its further development in the last decades due to computer science progress. The simulation modeling represents a description of behaviour dynamics of the system explored. The main feature of simulation modeling is the fact that every execution of the machine gives information that is valid only under certain entry parameters given before the execution. In other words, the results of the simulation process execution will depend on the specific values of a series of parameters. The main task of this study was exploring the use of simulation models in economic processes. The results obtained during the imitation studies are able to provide data that will help to make the right decision under different scenarios of the situation development. At the same time, simulation modeling has a number of shortcomings, among which the difficulty of perception due to mathematical complexity, the difficulty of 
development and some inaccuracy of the results obtained. In economic analysis it is important to establish cause-effect relationships, as well as the characteristics of the mutual influence of the parameters on each other. The type of simulation modeling such as "system dynamics》 allows us to establish the nature and essence of the processes occurring in the system explored. Simulation modeling is a research method that allows you to study the features and properties of complex systems. The use of simulation modeling in management activities makes it possible to analyze the possible development of the situation in certain initial conditions and helps to make the right decision. This method of analysis is widely used in various sectors of the economy, including the management of human resources of enterprises. For example, it allows to predict the dynamics of changes in labor productivity or to assess the future need for qualified specialists.

Key words: simulation modeling, covariance, correlation, model verification, validation, determination of the degree of adequacy.

Постановка проблеми. Для економічного аналізу важливим є встановлення причинно-наслідкових зв'язків та особливостей взаємного впливу параметрів один на одного. Вигляд імітаційного моделювання «системна динаміка» дає змогу встановити природу і сутність процесів, які відбуваються в системі, що вивчається.

Водночас імітаційне моделювання має низку недоліків, серед яких - математична складність, труднощі в розробленні алгоритмів моделювання та суттєва неточність одержуваних результатів. Отримані під час виконання імітаційних досліджень дані забезпечують прийняття оптимальних рішень за різних сценаріїв розвитку ситуації.

Аналіз останніх досліджень і публікацій. Нині склалася практика імітаційного моделювання, за якої використовуються певні підходи та концепції, що дають змогу встановити рівень достовірності імітаційної моделі. Загалом проблему достовірності відносять до «вічних» проблем моделювання. Справа в тому, що порівняно з іншими методами дослідження імітаційне моделювання не здатне забезпечити проєктувальників відповідними формальними засобами опису багатьох процесів.

Існує значна кількість робіт, присвячених оцінці достовірності імітаційних моделей. Відомі роботи таких авторів, як О.В. Вавілов, Дж. Клейнен, Н.П. Бусленко та ін.

Значний прогрес у підвищенні ступеня достовірності імітаційних моделей відбувся в середині 90-х років XX ст. У цей час американськими дослідниками було виконано низку наукових праць зі створення методологічних схем. Здійснення достовірності було вперше розглянуто як процес, що складається з багатьох етапів та ітерацій. Щодо підвищення правдивості, було виділено такі основні категорії оцінки:

- верифікація моделі;

- валідація;

- визначення ступеня адекватності.

Під терміном «валідація» розуміється перевірка моделі, коли порівнюється задана поведінка з фактичною. Інакше кажучи, валідація дає змогу встановити відповідність моделі заданим вимогам. На етапі валідації проводиться низка тестових досліджень створеної моделі.

Верифікація моделі дає змогу довести можливість іiі використання у вигляді комп'ютерного аналога логічної (концептуальної) моделі за рахунок високого рівня відповідності. Ця процедура проводиться з метою встановлення рівня, за якого досягається схожість моделі з реальною системою.

Валідація і верифікація дають змогу контролювати внутрішню структуру моделі, відповідність моделі тим гіпотезам, які було прийнято. Тут підтверджується або спростовується точність даних, що використовуються в моделі, складаються прогнози, що $\epsilon$ частиною проблемного аналізу. Під проблемним аналізом розуміються висновки, отримані під час експерименту з імітаційною моделлю. Тут першочергово важливими $€$ чутливість, стійкість та точність результатів моделювання.

Формулювання цілей статті. У моделюванні економічних процесів обчислювальний експеримент розглядається як новий метод наукового дослідження. При цьому 
подібний експеримент є повноцінним науковим дослідженням, що базується на імітаційній моделі. Останнє дає змогу отримати відомості та сформулювати висновки, які можуть вплинути на подальші рішення. При цьому модель виконує своє головне призначення - забезпечення достовірними даними у мінливих умовах.

Цілі імітаційного моделювання формулюються під час попереднього аналізу, який $\epsilon$ частиною наукового експерименту.

Дані, представлені вище, дають змогу зробити висновок, що завдання, що ставляться під час проведення імітаційного дослідження, складаються з таких елементів, як:

- стратегічне прогнозування майбутнього дослідження;

- підбір оптимального методу обробки даних, отриманих у результаті обчислювального експерименту;

- створення алгоритму реалізації експерименту.

Планування експерименту має двоякий характер. По-перше, попереднє прогнозування дає змогу вибрати конкретний спосіб отримання необхідної інформації прийняття подальших рішень. По-друге, таке планування дає можливість досягти цілей дослідження найефективнішим способом. Правильно підібрані методи статистичної обробки даних дають змогу правильно інтерпретувати отримані дані [4].

Важливим завданням під час планування імітаційного експерименту є вибір способу аналізу результатів. Саме цілі та завдання дослідження визначають набір застосовуваних математичних методів. У цілому ж імітаційна модель може бути розглянута як якийсь чорний ящик, у якому встановлено взаємозв'язок між входом та виходом. $\mathrm{Y}$ цьому регресивна модель $\epsilon$ найпростішим випадком, у якому функція $\mathrm{F}$ обчислюється як інтерполяція [2].

Складні системи мають у своєму складі безліч функціональних компонентів, на які в будь-який час діють різноманітні фактори різної природи і мають різну невизначеність [5].

У подібних системах причину зі слідством рознесено один від одного, а короткострокові рішення мають бути узгоджені з довгостроковими прогнозами. У таких непростих умовах наявність комп'ютерної моделі, що імітує ту чи іншу економічну систему, може бути ефективним інструментом у руках державного службовця чи керівника великої комерційної організації. Наявність такої моделі дає змогу виробити ефективні рішення проблем, що в результаті дасть можливість зберегти не лише фінанси, а й організацію у цілому. Головною перевагою імітаційного моделювання є можливість проведення експерименту без участі у ньому реальної системи. Проведення імітаційних експериментів дає змогу відповісти на запитання «що якщо...?» і тому знаходить найширше застосування у таких сферах економіки, як консалтинг, операційний та виробничий менеджмент, а також у державному та територіальному управлінні.

Виклад основного матеріалу. Актуальність цієї статті не викликає сумніву, оскільки математична модель показує, яка очікується зміна обстановки у відповідь на це рішення і до яких наслідків воно призведе через деякий час.

Застосування імітаційного моделювання за умов української економіки під час аналізу фінансової ситуації має значення. Справа в тому, що економіка нашої країни відрізняється високим ступенем невизначеності та суб'єктивності, залежністю від неекономічних чинників.

Практична значущість статті зумовлена тим, що на етапі економічного розвитку імітаційне моделювання за своєю суттю $є$ найефективнішим і дуже часто єдиним способом вивчення складних проблем у сфері управління. В умовах постійного розвитку економічних систем і, як наслідок, дедалі більшого їх ускладнення таких суб'єктивних даних, як інтуїція, життєвий досвід та поради експертів, буває абсолютно недостатньо.

У процесі будь-якої діяльності людина постійно стикається з необхідністю приймати ті чи інші рішення та жити наслідками. Дуже часто масштаб наслідків прийняття помилкових рішень може бути настільки великим, що може призвести до катастро- 
фічних наслідків для країни. Під час прийняття рішень людина покладається на певні дані, які можуть мати як об'єктивний, так і суто суб'єктивний характер. Прикладом об'єктивних даних можуть бути рівень поточних нафтових цін або іноземної валюти, стан фінансових резервів. Суб'єктивні дані найчастіше пов'язані з життєвим досвідом конкретної людини, її оточення. Переплітаючись, об'єктивні та суб'єктивні дані у цілому формують у людини уявлення про ситуацію та безпосередньо впливають на прийняття нею тих чи інших рішень.

Принаймні вдосконалення людської цивілізації приймати правильні рішення, від яких залежали життя, і добробут цілих народів, виявлялося дедалі складніше. Поступово виникла необхідність створення інструментів, що дають змогу адекватно проаналізувати ситуацію, що складається, наприклад, в економіці, і на основі наявних даних приймати рішення, які цілком могли бути доленосними. Одним із таких інструментів $€$ метод імітаційного моделювання, який нині все частіше знаходить застосування для аналізу складних економічних систем. У цьому разі під імітаційним моделюванням розуміється проведення експериментів із застосуванням, будь-яких моделей об'єктів, у яких взаємодію між окремими елементами описано за допомогою математичних формул [1].

Порівняно з іншими методами досліджень імітаційне моделювання має низку переваг. По-перше, для вивчення системи із застосуванням даного методу немає необхідності використовувати саму систему - достатньо створити математичну модель, яка імітуватиме цю систему. Також важливою $є$ можливість виокремити із системи, що вивчається, певну частину і зрозуміти особливості їі взаємодії з іншими компонентами системи. Ураховуючи цей факт, саме імітаційне моделювання дуже добре підходить для вивчення економічних процесів як усередині організації, так і на макрорівні [2].

Дуже часто недолік відомостей про будь-який процес чи явище $є$ стримуючим чинником прийняття рішень. При цьому отримання даних, що відсутні, неможливе або значною мірою утруднене. У таких ситуаціях логічно застосовувати імітаційне моделювання зі складанням прогнозів розвитку ситуації. При цьому фактичні показники замінюються на дані, що зібрані в результаті моделювання.

Проведення імітаційного аналізу зазвичай здійснюється у кілька етапів, основними з яких є:

- виявлення залежності між вхідними та вихідними значеннями, вираженими у вигляді математичних формул;

- комп'ютерна візуалізація ключових параметрів досліджуваної моделі;

- обчислення основних характеристик для отримання даних;

- осмислення отриманих у результаті моделювання даних та прийняття рішень.

Залежно від конкретної ситуації для надання отриманим у результаті імітаційного моделювання даним необхідної однозначності вдаються до статистичної обробки даних.

Імітаційне моделювання економіки корисно ще й тим, що дає змогу мінімізувати витрати на збирання необхідних прийняття рішень даних. Основна мета імітаційного моделювання - визначити можливі варіанти поведінки досліджуваної системи [4].

Серед різноманіття підходів до вирішення завдань імітаційного моделювання можна виділити три основні. Перший - агентне моделювання, найчастіше застосовується вивчення систем із вираженою децентралізацією, під якою розуміється такий тип функціонування, який пов'язаний із будь-якими жорсткими правилами. Навпаки, правила є продуктом активності системи, що вивчається. У разі завдання імітаційного моделювання зводиться до вивчення правил і принципів, якими здійснюється функціонування цієї системи. У цьому разі математично описується поведінка окремих компонентів цієї системи. Такі окремі компоненти отримали назву агентів.

Інший метод імітаційного моделювання заснований на аналізі тільки ключових елементів системи, що вивчається. Тут не надається значення будь-яким окремим ком- 
понентам. Такий метод отримав назву дискретноподійний і широко використовується у різних галузях економіки.

Для визначення взаємозв'язку між двома множинами даних в імітаційному аналізі широко застосовуються коваріація і кореляція, що розраховується за формулою:

$$
\operatorname{Cov}(X, Y)=\frac{1}{m} \sum_{i=j}^{m}\left(X_{i}-M(X)\right)\left(Y_{i}-M(Y)\right),
$$

де $\mathrm{X}$ та $\mathrm{Y}$ є безліччю випадкових величин, а величина $\mathrm{m}$ характеризує розмірність цих величин. $\mathrm{M}(\mathrm{X})$ i $\mathrm{M}(\mathrm{Y})$ розглядаються як математичні очікування величин $\mathrm{X}$ i Y відповідно.

Позитивна коваріація матиме місце лише в тому разі, якщо більшим значенням X будуть відповідати великі значення Ү. Даний факт сигналізуватиме про тісну залежність між величинами. Навпаки, негативна коваріація має місце тоді, коли малим значенням Х відповідають великі значення Ү. У цьому залежність буде слабкою, а показник коваріації прагнутиме до нуля.

Значення коваріації залежать від одиниць виміру величин, які піддаються вивченню, що за певних умов є чинником, який обмежує використання цього методу практично. У цьому разі застосовується введення у розрахунки коефіцієнта кореляції. Слід ураховувати, що коефіцієнт кореляції має такі самі властивості, що і коваріація, проте водночас він $є$ величиною безрозмірною, а його значення можуть перебувати в діапазоні від -1 (у разі зворотного лінійного взаємозв'язку) до +1 (якщо взаємозв'язок прямий лінійний). Якщо ж досліджувані величини незалежні одна від одної, значення кореляції прагне до нуля.

Зараз у зв'язку з широким поширенням обчислювальної техніки для розрахунку кореляції та коваріації має сенс використовувати спеціальні комп'ютерні програми, зокрема MS Excel. Цей програмний продукт має всі необхідні функції для обчислення вищеназваних показників.

Загальновідомим є факт, що моделювання являє собою створення математичної моделі системи, що вивчається, і вимагає наявність відомостей про завдання іiї функціонування, можливих обмежень, які звужують область допустимих значень застосовуваних змінних. Аналіз подібної моделі дає можливість виявити шлях найбільш оптимального на керований об'єкт під час виконання будь-яких певних умов [3].

Велика кількість різних змінних та обмежень значно ускладнює процес імітаційного моделювання, тому завжди потрібно прагнути до вичленування із системи лише найбільш ключових параметрів та сфокусувати увагу саме на них. Таким чином, для успішного проведення імітаційного моделювання потрібно вміти визначати передусім пріоритетні параметри та обмеження.

Імітаційні моделі повинні переважно відтворювати поведінку досліджуваної системи протягом певного проміжку часу за рахунок визначення низки подій та умов, розподіл яких у часі дасть змогу отримати необхідну інформацію про систему. Така інформація, що накопичується у вигляді статистичних даних, має постійно оновлюватися під час виникнення певних подій. Імітаційні моделі дають змогу отримати дані про роботу складних систем, котрим неможливо створити математичну модель. Водночас імітаційне моделювання має низку недоліків. Тут, перш за все, необхідно наголосити на необхідності проведення дуже великої кількості експериментів, що, своєю чергою, неминуче веде до виникнення помилок.

Моделювання процесів економіки необхідне для оптимізації певної функції з урахуванням деяких обмежень. При цьому саме поняття «оптимізація» зазвичай застосовується для встановлення максимізації та мінімізації цієї досліджуваної функції. Так, наприклад, під час вибору максимізації прибутку або мінімізації виробничих витрат та використання однакових обмежень не завжди можна дійти до оптимального рішення. 
Тут визначальним чинником може бути загальна ситуація в економіці, зокрема спад споживання, спричинений фінансовою кризою. Відомо, що цей параметр не є контрольованим даною фірмою, а отже, застосування може спотворити імітаційну модель.

Зважаючи на вищесказане, отримання оптимального рішення під час використання математичної моделі може бути найбільш вигідним виключно в рамках цієї моделі за дотримання всіх умов. Іншими словами, отримане рішення $\epsilon$ найкращим лише в тому разі, коли прийняті критерії $є$ цілком достовірними та вибраними відповідно до завдань організації.

Важливо, що імітаційне моделювання являє собою експериментальний метод дослідження реально існуючої системи з побудованої моделі із властивими їй певними обмеженнями. Для того щоб краще зрозуміти особливості імітаційного моделювання, необхідно познайомитися з його структурою, в основі якої укладено чотири ключові компоненти:

- реально існуюча система;

- логіко-математична модель системи, що імітується;

- машинна модель системи;

- комп'ютер, на якому проводиться розрахунок моделі.

Під час здійснення процесу імітаційного моделювання необхідно враховувати правило, згідно з яким побудована модель має передавати логічну структуру та поведінкові особливості ії елементів. Також зміст системи, що вивчається, повинен відображатися у самій імітаційній моделі. Таким чином, іiі створення засноване на описі змісту та функціональних особливостей даної системи [5].

Під час створення моделі необхідно враховувати такі моменти:

- на етапі створення моделі важливим пунктом $є$ здійснення структурного аналізу досліджуваних процесів, а отже, необхідно статично охарактеризувати модельовану систему відповідно до ії змісту;

- для створення функціональної моделі необхідні також динамічний опис системи та взаємодія ії елементів.

На етапі програмної реалізації процесу імітації необхідно зіставити програмні компоненти, а їх стан позначити через змінні. Ураховуючи, що між окремими елементами моделі завжди відбувається обмін даними, важливо створити відповідний моделюючий алгоритм. Окрім цього, система існує в часі, а отже, потрібно обов'язково враховувати тимчасовий фактор.

Можливість імітації взаємодій між окремими компонентами системи є характерною рисою імітаційного моделювання. У зв'язку із цим для створення інформаційної моделі важливо:

- розглядати систему як сукупність окремих взаємодіючих елементів;

- математично описати функціонування кожного окремого елемента;

- створити механізм взаємодії різних компонентів моделі як між собою, так із зовнішнім середовищем.

Виявлення та математичний опис процесів, що мають перебіг у системі, $є$ найважливішою частиною імітаційного моделювання. Кожна певна комбінація параметрів системи, що моделюється, описує їхній конкретний стан, а отже, за зміни змінних можлива імітація переходу системи в інший стан.

Незалежно від конкретного типу моделі імітаційне моделювання можна розбити на кілька стадій:

- формулювання завдання моделювання, встановлення першочергових проблем дослідження. На цьому етапі складовою частиною процесу опису моделі є формалізація результатів вивчення;

- вибір методу формалізації об'єкта моделювання та визначення методу вербального опису; 
- надання об'єкту моделювання формального стилю та офіціалізація імітаційної моделі;

- створення програмного коду імітаційної моделі, його налагодження;

- здійснення тестування, верифікації моделі з метою її комплексного тестування, відповідність моделі заданим параметрам;

- створення прогнозу та здійснення імітаційного експерименту. Після завершення цього етапу відбувається отримання плану експерименту;

- проведення варіації підсумків діяльності та вироблення рішень для застосування результатів дослідження на практиці.

Після створення програмного коду моделі тестування є важливим та відповідальним кроком. Якщо цей етап буде пропущено, можливі помилки можуть призвести до спотворення як окремих елементів моделі, так і їі у цілому. Тут слід пам'ятати, що імітаційні моделі створюються, щоб оцінити точність, корисність і коректність даних, які допомагають приймати правильні рішення.

Відмінною рисою імітаційних моделей є високий рівень інформізму, під яким розуміється ступінь подібності даної моделі з вихідним об'єктом. У коректно складеній моделі збережено зв'язок та характер взаємодії з окремими компонентами.

Рівень деталізації моделі визначає ступінь її подібності до реальної системи. Збільшення цього показника є дуже трудомістким і не завжди необхідним. Навпаки, багато імітаційних моделей використовують спрощення, різні аналоги та абстракції реально існуючих систем. Також під час опису моделей завжди діє суб'єктивний чинник, уникнути якого часто неможливо, тому завжди слід визначити межу подібності моделі до реальної системи, не забуваючи при цьому переконатися, що створена модель відповідає вимогам функціональності, надійності та достовірності.

Висновки. Імітаційне моделювання є методом дослідження, який дає змогу вивчити особливості та властивості складних систем. Застосування імітаційного моделювання в управлінській діяльності дає можливість аналізу можливого розвитку ситуації за певних вихідних умов та допомагає прийняти правильне рішення. Цей метод аналізу широко застосовується у різних галузях економіки, зокрема й в управлінні людськими ресурсами підприємств. Наприклад, він дає змогу спрогнозувати динаміку зміни продуктивності праці або оцінити майбутню потребу у кваліфікованих спеціалістах.

\section{Список використаних джерел:}

1. Григорків В.С. Моделювання економіки : підручник. Чернівці : Чернівецький нац. ун-т ім. Ю. Федьковича, 2019. С. 348-355.

2. Глущевський В.В. Адаптивні механізми в системах управління підприємствами: методологія і моделі : монографія. Запоріжжя : КПУ, 2016. С. 42-52.

3. Бутко М.П., Задорожна С.М., Іванова Н.В. Виробничий менеджмент : підручник. Київ : Центр учбової літератури, 2015. С. 420-424.

4. Глущевський В.В. Методологія моделювання простору задач у системі управління. промисловим підприємством. Маркетинг і менеджмент інновацій. 2015. № 1. С. 124-134.

5. Казначеева С.Н., Репина Р.В. Проблеми адаптації персоналу в кадровому менеджменті. Науковедение. 2015. Т. 7. № 5(30). С. 28-35.

\section{References:}

1. Hryhorkiv V.S. (2019) Modelyuvannya ekonomiky [Economy model]: pidruchnyk. Chernivtsi: Chernivets'kyy nats. un-t im. Yu. Fed'kovycha, pp. 348-355.

2. Hlushchyevs'kyy V.V. (2016) Adaptyvni mekhanizmy u systemakh upravlinnya pidpryyemstvamy: metodolohiya ta modeli [Adaptive Mechanisms in Control Systems of Enterprises: Methodology and Models]: monohrafiya. Zaporizhzhya: KPU, pp. 42-52.

3. Butko M.P., Zadorozhna S.M., Ivanova N.V. (2015) Vyrobnychyy menedzhment [Production management]: pidruchnyk. Kyiv: Tsentr uchbovoyi literatury, pp. 420-424. 
4. Hlushchevs'kyy V.V. (2015) Metodolohiya modelyuvannya prostoru zadach u systemi upravlinnya promyslovym pidpryyemstvom [Methodology for modeling the task space in the control system industrial enterprise]. Marketynh $i$ menedzhment innovatsiy. Sumy: TOV VTD «Universytetska knyha», no. 1, pp. 124-134.

5. Kaznacheeva S.N., Repyna R.V. (2015) Problemy adaptatsiyi personalu v kadrovomu menedzhmenti [Problems of personnel adaptation in personnel management]. Ynternet-zhurnal Naukovedenye, t. 7 , no. 5(30), pp. $28-35$. 